
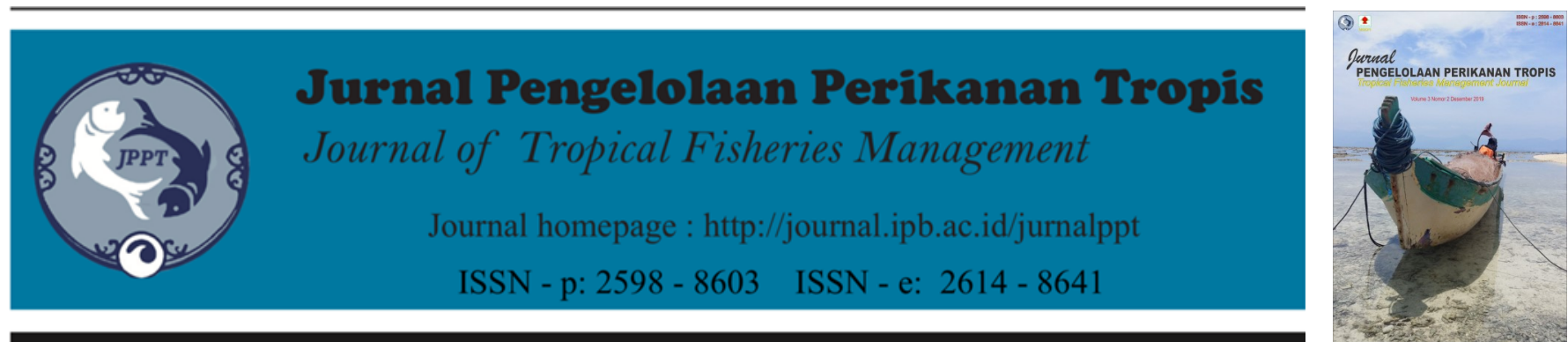

\title{
Analisis Keragaman Morfometrik Rajungan (Portunus pelagicus Linnaeus, 1758) di WPP 712 Sebagai Dasar Pengelolaan
}

\author{
(Analysis Morphometric Diversity of Blue Swimming Crab (Portunus pelagicus Linnaeus, 1758) \\ in FMA 712 As a Base Management)
}

\section{Alvia Safira*, Zairion, Ali Mashar}

Departemen Manajemen Sumberdaya Perairan, Fakultas Perikanan dan Ilmu Kelautan, Institut Pertanian Bogor

\begin{tabular}{|c|c|}
\hline ARTIKEL INFO & ABSTRACT \\
\hline & Blue swimming crab (Portunus pelagicus) is one of the fisheries resources that has a diverse \\
\hline $\begin{array}{l}\text { Recevied: } 24 \text { Agustus } 2019 \\
\text { Accepted: } 29 \text { Oktober } 2019\end{array}$ & \\
\hline $\begin{array}{l}\text { Keywords: } \\
\text { FMA 712, morphometrics, } \underline{P} \text {. } \\
\text { pelagicus }\end{array}$ & $\begin{array}{l}\text { analyze the condition of P. pelagicus unit stock from morphometric diversity. The locations are } \\
\text { in Lancang Island, Cirebon, and South Madura. The method to measure the morphometric } \\
\text { characters is conventional method. The results of Kruskall-Wallis analysis show there are } 4 \\
\text { distinguishing characters. The results of cluster analysis show that P. pelagicus in Cirebon and }\end{array}$ \\
\hline $\begin{array}{l}\text { Korespondensi Author } \\
\text { Alfia Safira, Departemen } \\
\text { Manajemen Sumberdaya }\end{array}$ & $\begin{array}{l}\text { Discriminant analysis shows there are three populations of P. pelagicus, population of Lancang } \\
\text { Island, Cirebon, and South Madura. All of the results show that P. pelagicus in WPP } 712 \text { might } \\
\text { have more than one stock unit potential. }\end{array}$ \\
\hline
\end{tabular}

Perairan, Fakultas Perikanan

dan Ilmu Kelautan, Institut

Pertanian Bogor.

Email: asafira97@gmail.com

\section{PENDAHULUAN}

Rajungan merupakan salah satu sumberdaya pesisir yang memiliki nilai ekonomi yang meningkat dari tahun ke tahun. Hal ini diakibatkan oleh permintaan ekspor rajungan yang tinggi setiap tahunnya. Penangkapan rajungan biasanya dilakukan di perairan pesisir hingga kedalaman $30 \mathrm{~m}$ (Zairion 2015). Rajungan (Portunus pelagicus) akan menetap di dasar perairan dan terkadang berenang ke permukaan untuk mencari makan (Mawaluddin et al. 2016). Sebaran rajungan (Portunus pelagicus) meliputi perairan pantai tropis mulai dari Samudera Hindia Barat, dan Samudera Pasifik bagian Timur (Kailola et al. 1993 in Ernawati et al. 2014) serta Indo-Pasifik Barat (Lai et al. 2010).

Rajungan memiliki habitat di daerah tepi pantai dan pesisir serta hidup pada substrat yang berpasir dan berlumpur, sehingga menyebabkan rajungan banyak dimanfaatkan secara langsung oleh nelayan karena dekat dengan tepi pantai dan memiliki nilai ekonomis tinggi (Sara et al. 2016). Keberadaan rajungan yang dimanfaatkan dipengaruhi oleh kondisi musim dikarenakan tersedianya stok makanan yang berlebih bagi rajungan (Nontji 1987 in Muhsoni \& Abida 2009). Pemanfaatan potensi sumberdaya yang ada akan berpengaruh terhadap kelestarian stok dari suatu populasi. Apabila pemanfaatan stok telah melebihi potensi yang ada, maka akan membahayakan kelestarian stok tersebut (Muhsoni \& Abida 2009).

Rajungan hidup pada perairan yang memiliki salinitas yang tinggi untuk melakukan pemijahan (Nybakken 1986 in Edi et al. 2018). Hal ini menyebabkan pola persebaran rajungan di perairan Indonesia menjadi beragam. Salah satu perairan Indonesia yang termasuk dalam wilayah persebaran rajungan adalah Laut Jawa. Laut Jawa merupakan suatu wilayah perikanan yang termasuk ke dalam Wilayah Pengelolaan Perikanan (WPP) 712. Menurut Kepmen KP No. 79 tahun 2016 WPP 712 merupakan salah satu daerah strategis penangkapan ikan dengan estimasi potensi sumberdaya rajungan sebesar 22.637 ton/tahun. Tingginya potensi pemanfaatan sumberdaya rajungan di WPP 712 tentunya memerlukan kajian lebih lanjut mengenai unit stok rajungan di wilayah tersebut sebagai dasar 
pengelolaan yang dapat dilihat dari keragaman morfometriknya. Wilayah yang digunakan untuk mewakili WPP 712 meliputi Pulau Lancang, Cirebon, dan Selatan Madura.

Keragaman morfometrik dapat digambarkan dalam bentuk morfologi sehingga memberikan informasi mengenai perbedaan kelompok populasi dalam suatu perairan. Perbedaan morfometrik dapat dijadikan sebagai evaluasi dari struktur populasi dalam mengidentifikasi suatu stok (Mojekwu \& Anumudu 2015). Penelitian mengenai keragaman morfometrik rajungan di Laut Jawa sudah pernah dilakukan sebelumnya oleh Aini (2017) dan Afifah (2017), namun masih sedikit informasi mengenai keragaman morfometrik yang didapat. Morfometrik merupakan suatu metode pengukuran yang dapat menggambarkan struktur tubuh (Muhotimah et al. 2013). Tujuan dari penelitian ini menganalisis keragaman morfometrik rajungan (Portunus pelagicus) di WPP 712 yang meliputi Pulau Lancang, Cirebon, dan Selatan Madura agar dapat menggambarkan kondisi unit stok rajungan (Portunus pelagicus) di WPP 712.

\section{METODE}

\section{Waktu dan lokasi penelitian}

Penelitian ini dilakukan dari bulan Juli 2018 hingga Maret 2019. Contoh rajungan (Portunus pelagicus) diambil dari tiga lokasi, yaitu Pulau Lancang (DKI Jakarta), Cirebon (Jawa Barat), dan Selatan Madura (Jawa Timur). Lokasi pengambilan contoh dapat dilihat pada Gambar 1. Analisis morfometrik dilaksanakan di Laboratorium Biologi Molekuler Akuatik, Departemen Manajemen Sumberdaya Perairan, Fakultas Perikanan dan Ilmu Kelautan, Institut Pertanian Bogor.
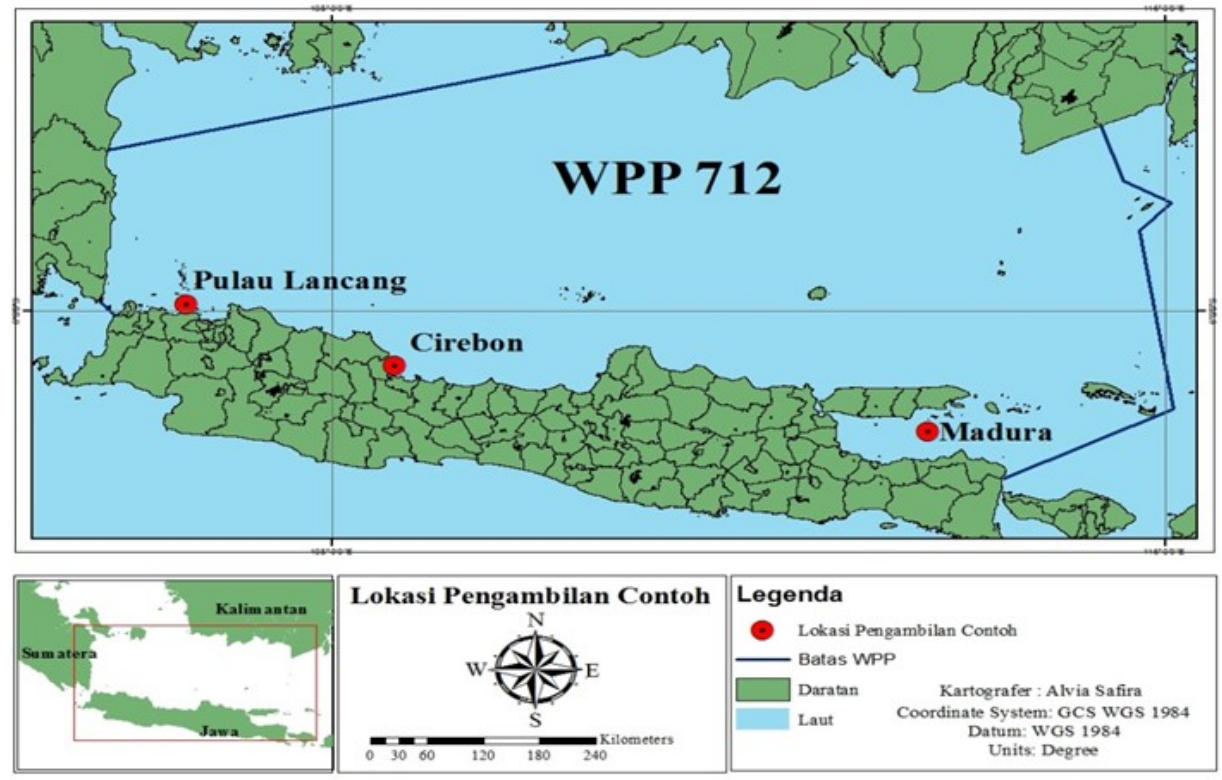

Gambar 1 Lokasi pengambilan contoh

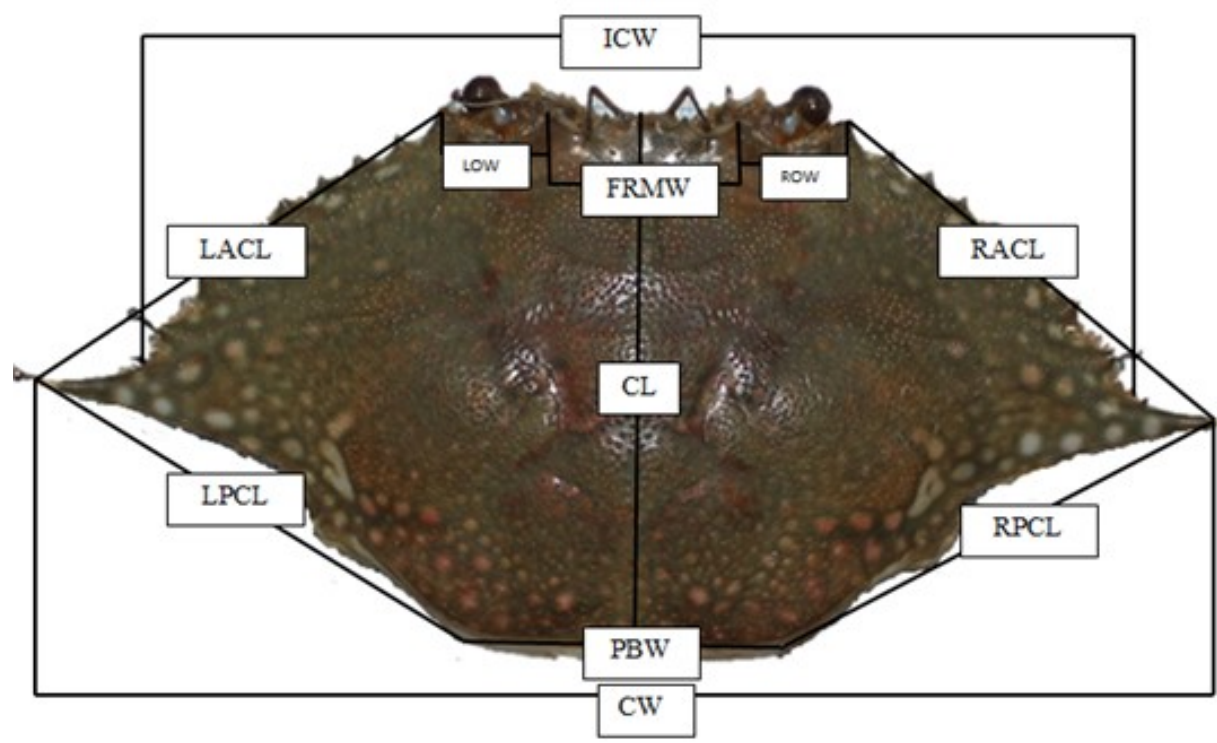

Gambar 2 Pengukuran karapas Portunus pelagicus menggunakan metode konvensional 


\section{Teknik Pengambilan Contoh}

Pengambilan contoh rajungan dilakukan dengan penarikan contoh acak sederhana. Contoh diambil dengan cara mengumpulkan rajungan (Portunus pelagicus) yang terdapat dari beberapa pengepul rajungan yang berada di tiga lokasi. Jumlah contoh rajungan yang diambil di Pulau Lancang, Cirebon, dan Selatan Madura sebanyak 106, 91, dan 105 ekor. Rajungan yang telah diperoleh disimpan terlebih dahulu di dalam freezer sebelum diukur.

\section{Proses Pengukuran Contoh}

Pengukuran karakter morfometrik dengan metode konvensional dilakukan dengan menggunakan kaliper digital dan bantuan software ImageJ. Pengukuran dengan metode konvensional meliputi 11 karakter pada karapas (Gambar 2).

Pengukuran dengan software ImageJ dilakukan dengan mengatur skala yang telah ditentukan berdasarkan skala gambar serta skala aslinya. Hasil pengukuran yang didapat dari software akan menggambarkan skala asli pada rajungan. Penggunaan software ImageJ dilakukan agar hasil pengukuran lebih akurat. Karakter yang diukur pada karapas dengan menggunakan metode konvensional dapat dilihat pada Tabel 1 (Aini 2017).

\section{Analisis data}

\section{Hubungan Lebar Karapas dan Bobot}

Pola pertumbuhan rajungan dapat dilihat melalui analisis hubungan lebar karapas dan bobot. Rumus hubungan lebar karapas dan bobot digambarkan dengan persamaan berikut (King 2007) :

$$
\mathrm{W}=\mathrm{aCW}
$$

Keterangan:

$\mathrm{W}=$ Bobot (gram)

$$
\begin{array}{ll}
\mathrm{CW} & =\text { lebar karapas }(\mathrm{mm}) \\
\mathrm{a} & =\text { konstanta } \\
\mathrm{b} & =\text { slope (laju pertumbuhan) }
\end{array}
$$

Bentuk linear dari persamaan tersebut ditulis sebagai :

$$
\log W=\log a+b \log C W
$$

Pendugaan parameter $\mathrm{a}$ dan $\mathrm{b}$ didapat melalui analisis regresi linear sederhana. Hasil dari analisis regresi linear sederhana berupa nilai $b$ yang sama dengan 3 atau tidak sama dengan 3. Selanjutnya, dilakukan uji t lanjut untuk melihat nilai konstanta $b$ dengan hipotesa nol $\left(\mathrm{H}_{0}\right)$, yaitu $\mathrm{b}=3$ dan hipotesa satu $\left(\mathrm{H}_{1}\right)$, yaitu $\mathrm{b} \neq 3$. Perhitungan statistik yang digunakan, yaitu :

$$
\mathrm{T}_{\text {hitung }}=\left|\frac{\mathrm{b}-3}{\mathrm{Sb}}\right|
$$

$\mathrm{Sb}$ adalah simpangan baku dugaan $\mathrm{b}$ yang merupakan akar dari $\mathrm{Sb}^{2}$ dengan rumus sebagai berikut.

$$
\mathrm{Sb}^{2}=\left|\frac{\mathrm{s}^{2}}{\operatorname{Sigma} \mathrm{x}^{2}-\left(\left(\frac{1}{\mathrm{n}}\right)(\operatorname{sigma})^{2}\right)}\right|
$$

Nilai $t_{\text {hitung }}$ akan dibandingkan dengan nilai $t_{\text {tabel }}$ pada SK $95 \%$. Jika nilai $t_{\text {hitung }}$ lebih kecil dari $t_{\text {tabel }}$ maka gagal tolak $\mathrm{H}_{0}$, dimana $\mathrm{H}_{0}$ adalah $\mathrm{b}=3$. Hasil yang didapat dari hipotesa tersebut adalah pola pertumbuhan isometrik dengan pertumbuhan lebar karapas sama dengan bobot. Jika $t_{\text {hitung }}$ lebih besar dari $t_{\text {tabel}}$, maka tolak $\mathrm{H}_{0}$, dengan hasil yang didapat adalah pola pertumbuhan alometrik. Pola pertumbuhan alometrik dibagi menjadi dua, yaitu alometrik positif $(\mathrm{b}>3)$ dan alometrik negatif $(b<3)$ (Effendie 2002).

Tabel 1 Karakter karapas pada Portunus pelagicus yang digunakan dalam pengukuran menggunakan metode konvensional

\begin{tabular}{lll}
\hline No & Karakter & Keterangan \\
\hline 1 & CW (Carapace width) & Lebar karapas \\
2 & ICW (Internal carapace width) & Lebar karapas internal \\
3 & CL (Carapace length) & Panjang atau tinggi karapas \\
4 & LACL (Left anterolateral carapace length) & Lebar anterolateral karapas kiri \\
5 & RACL (Right anterolteral carapace length) & Lebar anterolateral karapas kanan \\
6 & LPCL (Left posterolateral carapace length) & Panjang atau tinggi posterolateral karapas kiri \\
7 & RPCL (Right posterolateral carapace length) & Panjang atau tinggi posterolateral karapas kanan \\
8 & FRMW (Frontal margin width) & Lebar duri frontal \\
9 & LOW (Left orbit width) & Jarak atau lebar orbit (rongga mata) kiri \\
10 & ROW (Right orbit width) & Jarak atau lebar orbit (rongga mata) kanan \\
11 & PBW (Posterior margin) & Lebar posterior karapas \\
\hline
\end{tabular}




\section{Hubungan Panjang Karapas dan Lebar Karapas}

Hubungan antara panjang karapas dan lebar karapas dianalisis dengan menggunakan regresi sederhana (Steel \& Torrie 1993). Lebar karapas digunakan sebagai variabel independen dan panjang karapas digunakan sebagai variabel dependen. Persamaan dari hubungan tersebut akan didapatkan melalui hasil analisis regresi sederhana (Aini 2017). Persamaan regresi dihitung dengan asumsi persamaan alometrik pertumbuhan untuk menentukan hubungan antara karakter morfometrik yang berbeda pada rajungan (Josileen 2011).

Perbedaan pola pertumbuhan akan dilakukan melalui pengujian nilai slope dan intercept melalui analisis covariance (ANCOVA). Perbedaan nilai slope akan menunjukkan adanya perbedaan laju pertumbuhan antar lokasi, sedangkan nilai intercept menggambarkan pengaruh dari lokasi yang diuji. Hal ini dilakukan saat hubungan antara lokasi dengan panjang karapas (nilai slope) tidak berbeda secara signifikan atau bersifat paralel. Apabila nilai pengaruh lokasi berbeda secara signifikan $(p<$ $0,05)$, maka terdapat perbedaan lebar karapas pada ukuran panjang karapas yang sama (Aini 2017).

\section{Perbandingan Karakter Morfometrik}

Perbandingan karakter morfometrik dilakukan melalui analisis Kruskal-Wallis. Perbandingan tersebut diketahui melalui perbedaan karakter morfometrik yang ada pada rajungan dari ketiga lokasi yang berbeda. Analisis Kruskal-Wallis adalah teknik statistika nonparametrik yang digunakan untuk menguji hipotesis awal bahwa beberapa contoh berasal dari populasi yang sama (Ostertagová et al. 2014).
Analisis Tingkat Kemiripan Populasi

Analisis tingkat kemiripan populasi Portunus pelagicus dari ketiga lokasi akan dilakukan menggunakan analisis kluster. Analisis kluster digunakan untuk menentukan kemiripan antar kelompok yang terbentuk berdasarkan karakter morfometrik. Hasil analisis pengelompokkan digambarkan dalam bentuk dendrogram dengan jarak euclidean, yaitu jarak yang menggambarkan kekerabatan rajungan antar lokasi.

\section{Analisis Pengklasifikasian Karakter Morfometrik}

Karakter morfometrik akan dikelompokkan ke dalam grup tertentu menggunakan analisis diskriminan. Analisis diskriminan dilakukan untuk menentukan pengelompokkan populasi berdasarkan perbedaan lokasi. Ukuran tubuh atau karakter morfometrik yang memiliki nilai sama menunjukkan adanya percampuran populasi yang terukur antara populasi satu dengan yang lainnya. Hasil yang didapatkan dari analisis ini adalah terpisah atau tidak terpisahnya centroid dari lokasi yang dianalisis.

\section{HASIL DAN PEMBAHASAN}

Hasil

\section{Ukuran Lebar Karapas dan Bobot}

Hasil nilai rata-rata dan simpangan baku dari ukuran lebar karapas dan bobot rajungan disajikan pada Tabel 2. Berdasarkan hasil yang didapat ukuran lebar karapas maksimal didapatkan pada lokasi Pulau Lancang untuk rajungan jantan $(154,339 \pm 13,601 \mathrm{~mm})$ dan Cirebon untuk rajungan betina $(157,947 \pm 11,449$ $\mathrm{mm})$. Ukuran bobot yang paling rendah didapatkan pada lokasi Selatan Madura untuk rajungan jantan dan betina.

Tabel 2 Nilai maksimum, minimum, rata-rata, dan simpangan baku dari ukuran lebar karapas dan bobot rajungan (Portunus pelagicus) di Pulau Lancang, Cirebon, dan Selatan Madura

\begin{tabular}{|c|c|c|c|c|c|c|c|c|c|}
\hline \multirow[b]{2}{*}{ Lokasi } & \multirow[b]{2}{*}{$\mathrm{N}$} & \multicolumn{4}{|c|}{ Lebar karapas (mm) } & \multicolumn{4}{|c|}{ Bobot $(\mathrm{g})$} \\
\hline & & Minimal & Maksimal & $\begin{array}{c}\text { Rata- } \\
\text { Rata }\end{array}$ & $\mathrm{Sb}$ & Minimal & $\begin{array}{c}\text { Maksi- } \\
\text { mal }\end{array}$ & $\begin{array}{c}\text { Rata- } \\
\text { Rata }\end{array}$ & $\mathrm{Sb}$ \\
\hline \multicolumn{10}{|l|}{ Jantan } \\
\hline Pulau Lancang & 19 & 106,186 & 154,339 & 137,283 & 11,456 & 127,300 & 271,100 & 192,316 & 46,864 \\
\hline Cirebon & 21 & 91,922 & 152,305 & 112,763 & 13,601 & 47,000 & 258,000 & 91,843 & 44,377 \\
\hline Selatan Madura & 82 & 71,126 & 154,036 & 119,543 & 13,977 & 22,600 & 247,400 & 116,757 & 42,882 \\
\hline \multicolumn{10}{|l|}{ Betina } \\
\hline Pulau Lancang & 18 & 111,337 & 156,328 & 132,327 & 11,116 & 83,100 & 224,400 & 143,772 & 36,559 \\
\hline Cirebon & 71 & 102,687 & 157,947 & 130,096 & 11,449 & 59,700 & 268,000 & 148,176 & 47,152 \\
\hline Selatan Madura & 23 & 91,846 & 144,789 & 112,684 & 17,785 & 34,400 & 182,300 & 83,665 & 42,544 \\
\hline
\end{tabular}




\section{Hubungan Lebar Karapas dan Bobot}

Analisis mengenai hubungan lebar karapas dan bobot dilakukan untuk mengetahui pola pertumbuhan dari rajungan. Pola pertumbuhan pada rajungan betina di Pulau Lancang dan Selatan Madura serta rajungan jantan di Cirebon dan Selatan Madura adalah Isometrik (Tabel 3). Pola pertumbuhan isometrik memiliki arti bahwa pola pertambahan bobot dan lebar karapas seimbang. Sementara itu, pola pertumbuhan yang didapat pada rajungan jantan di Pulau Lancang adalah alometrik negatif yang menandakan bahwa pola pertambahan lebar karapas lebih dominan dibandingkan dengan pola pertambahan bobot. Pola pertumbuhan yang didapatkan pada rajungan betina di Cirebon adalah alometrik positif yang memiliki arti pola pertambahan bobot lebih domi- nan dibandingkan dengan pola pertambahan lebar karapas.

\section{Hubungan Panjang Karapas dan Lebar Karapas}

Hubungan lebar karapas (CW) terhadap panjang karapas (CL) pada rajungan jantan dan betina di Pulau Lancang dengan Cirebon memiliki nilai yang tidak berbeda nyata $(p>0,05)$ atau paralel (Tabel 4). Hal ini menunjukkan bahwa laju pertumbuhan panjang karapas rajungan jantan dan betina di Pulau Lancang dengan Cirebon adalah sama. Sementara itu, laju pertumbuhan panjang karapas rajungan jantan serta betina pada lokasi Pulau Lancang dengan Selatan Madura serta Cirebon dengan Selatan Madura berbeda signifikan atau non paralel dengan nilai $p$

Tabel 3 Hubungan lebar karapas dan bobot rajungan (Portunus pelagicus) di Pulau Lancang, Cirebon, dan Selatan Madura

\begin{tabular}{lcllllll}
\multicolumn{1}{c}{ Lokasi } & $\mathbf{n}$ & Persamaan* & $\mathbf{r}^{\mathbf{2}}$ & $\mathbf{S b}$ & $\mathbf{T}_{\text {hitung }} *$ & $\mathbf{T}_{\text {tabel }} *$ & Pola Pertumbuhan \\
\hline Jantan & & & & & & & \\
Pulau Lancang & 19 & $\mathrm{~W}=0,0625 \mathrm{CW}^{1,6276}$ & 0,3625 & 0,5235 & 2,6215 & 2,4581 & Alometrik negatif \\
Cirebon & 21 & $\mathrm{~W}=0,00005 \mathrm{CW}^{3,0489}$ & 0,8691 & 0,2715 & 0,1803 & 2,4334 & Isometrik \\
$\begin{array}{l}\text { Selatan Madura } \\
\text { Betina }\end{array}$ & 82 & $\mathrm{~W}=0,00008 \mathrm{CW}^{2,9668}$ & 0,7821 & 0,1751 & 0,5270 & 2,2844 & Isometrik \\
$\begin{array}{l}\text { Pulau Lancang } \\
\text { Cirebon }\end{array}$ & 18 & $\mathrm{~W}=0,00010 \mathrm{CW}^{2,8909}$ & 0,8323 & 0,3244 & 0,3365 & 2,4729 & Isometrik \\
Selatan Madura & 23 & $\mathrm{~W}=0,0001 \mathrm{CW}^{2,8797}$ & 0,8835 & 0,2282 & 0,1897 & 2,2844 & Isometrik \\
\hline
\end{tabular}

Keterangan: $\left(^{*}\right)$ Apabila nilai $\mathrm{t}_{\text {hitung }}<\mathrm{t}_{\text {tabel }}$ maka gagal tolak $\mathrm{H}_{0}$ dimana pola pertumbuhan Isometrik. Apabila nilai $\mathrm{t}_{\text {hitung }}>\mathrm{t}_{\text {tabel }}$ maka tolak $\mathrm{H}_{0}$ dimana pola pertumbuhan allometrik dengan menyesuaikan nilai b yang terdapat dalam persamaan

Tabel 4 Hubungan lebar karapas (CW) terhadap panjang karapas (CL) rajungan (Portunus pelagicus)

\begin{tabular}{|c|c|c|c|c|c|}
\hline Lokasi & Persamaan $y=a+b x$ & $\mathbf{P}$ & $\mathbf{r}^{2}$ & $\mathbf{b}$ & $\mathbf{a}$ \\
\hline \multicolumn{6}{|c|}{ Hubungan antara $\mathrm{CW}$ terhadap $\mathrm{CL}$} \\
\hline \multicolumn{6}{|l|}{ Jantan } \\
\hline Pulau Lancang & $\mathrm{CL}=0,2305+1,1482 \mathrm{CW}$ & 0,05 & 0,9810 & Paralel & $\mathrm{a} 1=\mathrm{a} 2$ \\
\hline Cirebon & $\mathrm{CL}=0,2152+1,1639 \mathrm{CW}$ & 0,05 & 0,9680 & $p>0,05$ & $p>0,05$ \\
\hline Pulau Lancang & $\mathrm{CL}=0,2305+1,1482 \mathrm{CW}$ & 0,05 & 0,9810 & Non Paralel & \multirow{2}{*}{-} \\
\hline Selatan Madura & $\mathrm{CL}=0,3429+1,0737 \mathrm{CW}$ & 0,05 & 0,9569 & $p<0,05$ & \\
\hline Cirebon & $\mathrm{CL}=0,2152+1,1639 \mathrm{CW}$ & 0,05 & 0,9680 & Non Paralel & \multirow{2}{*}{-} \\
\hline Selatan Madura & $\mathrm{CL}=0,3429+1,0737 \mathrm{CW}$ & 0,05 & 0,9569 & $p<0,05$ & \\
\hline \multicolumn{6}{|l|}{ Betina } \\
\hline Pulau Lancang & $\mathrm{CL}=0,3634+1,0532 \mathrm{CW}$ & 0,05 & 0,9747 & Paralel & $\mathrm{a} 1 \neq \mathrm{a} 2$ \\
\hline Cirebon & $\mathrm{CL}=0,1893+1,1889 \mathrm{CW}$ & 0,05 & 0,9313 & $p>0,05$ & $p<0,05$ \\
\hline Pulau Lancang & $\mathrm{CL}=0,3634+1,0532 \mathrm{CW}$ & 0,05 & 0,9747 & Non Paralel & \multirow{2}{*}{-} \\
\hline Selatan Madura & $\mathrm{CL}=0,2956+1,1031 \mathrm{CW}$ & 0,05 & 0,9627 & $p<0,05$ & \\
\hline Cirebon & $\mathrm{CL}=0,1893+1,1889 \mathrm{CW}$ & 0,05 & 0,9313 & Non Paralel & \multirow[b]{2}{*}{-} \\
\hline Selatan Madura & $\mathrm{CL}=0,2956+1,1031 \mathrm{CW}$ & 0,05 & 0,9627 & $p<0,05$ & \\
\hline
\end{tabular}


$<0,05$. Hal ini menunjukkan bahwa laju pertumbuhan relatif panjang karapas rajungan jantan dan betina di Pulau Lancang dengan Selatan Madura serta Cirebon dengan Selatan Madura berbeda signifikan.

Perlu dilakukan uji intercept antara lokasi Pulau Lancang dengan Cirebon. Nilai intercept yang didapat rajungan betina di Pulau Lancang dengan Cirebon memberikan hasil yang berbeda nyata $(p<0,05)$. Hal tersebut menunjukkan bahwa terdapat perbedaan panjang karapas pada ukuran lebar karapas yang sama untuk rajungan betina di Pulau Lancang dengan Cirebon.

Hubungan panjang karapas (CL) terhadap lebar karapas internal (ICW) pada rajungan bersifat paralel dan non paralel. Rajungan jantan dan betina pada Pulau Lancang dengan Cirebon serta Cirebon dengan Selatan Madura serta rajungan betina di Pulau Lancang dan Selatan Madura bersifat paralel yang selanjutnya dilakukan uji intercept. Nilai intercept menunjukkan tidak adanya perbedaan ukuran panjang karapas pada lebar karapas internal yang sama. Adapun pada rajungan jantan di Pulau Lancang dan Selatan Madura memiliki sifat non paralel, dimana laju pertumbuhan panjang karapasnya tidak sama (Tabel 5).

\section{Perbandingan karakter morfometrik}

Hasil analisis dari ketiga lokasi menunjukkan adanya karakter yang berbeda $(p<0,05)$ pada pengukuran dengan metode konvensional (Tabel 6). Secara keseluruhan terdapat 7 karakter pembeda (dari 11 karakter) yang menjadi pembeda rajungan (Portunus pelagicus) jantan dari ketiga lokasi dengan metode konvensional.

Hasil analisis dari ketiga lokasi menunjukkan adanya karakter yang berbeda $(p<0,05)$ pada pengukuran dengan metode konvensional (Tabel 7). Secara keseluruhan terdapat 4 karakter

Tabel 5 Hubungan lebar karapas internal (ICW) terhadap panjang karapas (CL) rajungan (Portunus pelagicus)

\begin{tabular}{llllll}
\hline Lokasi & \multicolumn{1}{c}{ Persamaan $\mathbf{y}=\mathbf{a}+\mathbf{b x}$} & $\mathbf{P}$ & $\mathbf{r}^{2}$ & $\mathbf{b}$ & $\mathbf{a}$ \\
\hline \multicolumn{5}{c}{ Hubungan antara ICW terhadap $\mathbf{C L}$} \\
\hline Jantan & $\mathrm{CL}=0,4539+1,0548 \mathrm{ICW}$ & 0,05 & 0,9873 & Paralel & $\mathrm{a} 1=\mathrm{a} 2$ \\
Pulau Lancang & $\mathrm{CL}=0,4425+1,0623 \mathrm{ICW}$ & 0,05 & 0,9662 & $p>0,05$ & $p>0,05$ \\
Cirebon & $\mathrm{CL}=0,4539+1,0548 \mathrm{ICW}$ & 0,05 & 0,9873 & Non Paralel & - \\
\hline Pulau Lancang & $\mathrm{CL}=0,4859+1,0435 \mathrm{ICW}$ & 0,05 & 0,9751 & $p<0,05$ & \\
Selatan Madura & $\mathrm{CL}=0,4425+1,0623 \mathrm{ICW}$ & 0,05 & 0,9662 & Paralel & $\mathrm{a} 1=\mathrm{a} 2$ \\
\hline Cirebon & $\mathrm{CL}=0,4859+1,0435 \mathrm{ICW}$ & 0,05 & 0,9751 & $p>0,05$ & $p>0,05$ \\
Selatan Madura & & & & & \\
\hline Betina & $\mathrm{CL}=0,5823+1,0006 \mathrm{ICW}$ & 0,05 & 0,9893 & Paralel & $\mathrm{a} 1=\mathrm{a} 2$ \\
\hline Pulau Lancang & $\mathrm{CL}=0,5443+1,0153 \mathrm{ICW}$ & 0,05 & 0,9665 & $p>0,05$ & $p>0,05$ \\
Cirebon & $\mathrm{CL}=0,5823+1,0006 \mathrm{ICW}$ & 0,05 & 0,9893 & Paralel & $\mathrm{a} 1=\mathrm{a} 2$ \\
\hline Pulau Lancang & $\mathrm{CL}=0,5447+1,0156 \mathrm{ICW}$ & 0,05 & 0,9822 & $p>0,05$ & $p>0,05$ \\
Selatan Madura & $\mathrm{CL}=0,5443+1,0153 \mathrm{ICW}$ & 0,05 & 0,9665 & Paralel & $\mathrm{a} 1=\mathrm{a} 2$ \\
\hline Cirebon & $\mathrm{CL}=0,5447+1,0156 \mathrm{ICW}$ & 0,05 & 0,9822 & $p>0,05$ & $p>0,05$ \\
Selatan Madura & &
\end{tabular}

Tabel 6 Karakter morfometrik rajungan (Portunus pelagicus) jantan yang berbeda dengan metode konvensional

\begin{tabular}{clc}
\hline No & \multicolumn{1}{c}{ Karakter } & $\boldsymbol{p}$ - value \\
\hline 1 & ICW (Internal carapace width) & 0,004 \\
2 & CL (Carapace length) & 0,003 \\
3 & LACL (Left anterolateral carapace length) & 0,000 \\
4 & RPCL (Right posterolateral carapace length) & 0,000 \\
5 & FRMW (Frontal margin width) & 0,024 \\
6 & LOW (Left orbit width) & 0,000 \\
7 & ROW (Right orbit width) & 0,000 \\
\hline
\end{tabular}


pembeda (dari 11 karakter) yang menjadi pembeda rajungan (Portunus pelagicus) betina dari ketiga lokasi.

\section{Analisis Tingkat Kemiripan Populasi}

Berdasarkan hasil yang didapat dari pengukuran dengan metode konvensional menunjukkan bahwa rajungan jantan dan betina yang terdapat di Pulau Lancang dan Cirebon masih memiliki tingkat kemiripan karakter morfometrik yang sama, sehingga membentuk satu kelompok (Gambar 3). Lokasi Selatan Madura memiliki perbedaan terhadap karakter morfometriknya diantara Pulau Lancang dan Cirebon sehingga membentuk satu kelompok yang terpisah.

\section{Analisis Pengklasifikasian Karakter Morfometrik}

Hasil analisis menunjukkan bahwa populasi rajungan dari ketiga lokasi tidak terpisah secara sempurna (Gambar 4). Rajungan yang terdapat di

Tabel 7 Karakter morfometrik rajungan (Portunus pelagicus) betina yang berbeda dengan metode konvensional

\begin{tabular}{llc}
\hline No & Karakter & p-value \\
\hline 1 & ICW (Internal carapace width) & 0,039 \\
2 & CL (Carapace length) & 0,000 \\
3 & LACL (Left anterolateral carapace length) & 0,000 \\
4 & FRMW (Frontal margin width) & 0,007 \\
\hline
\end{tabular}
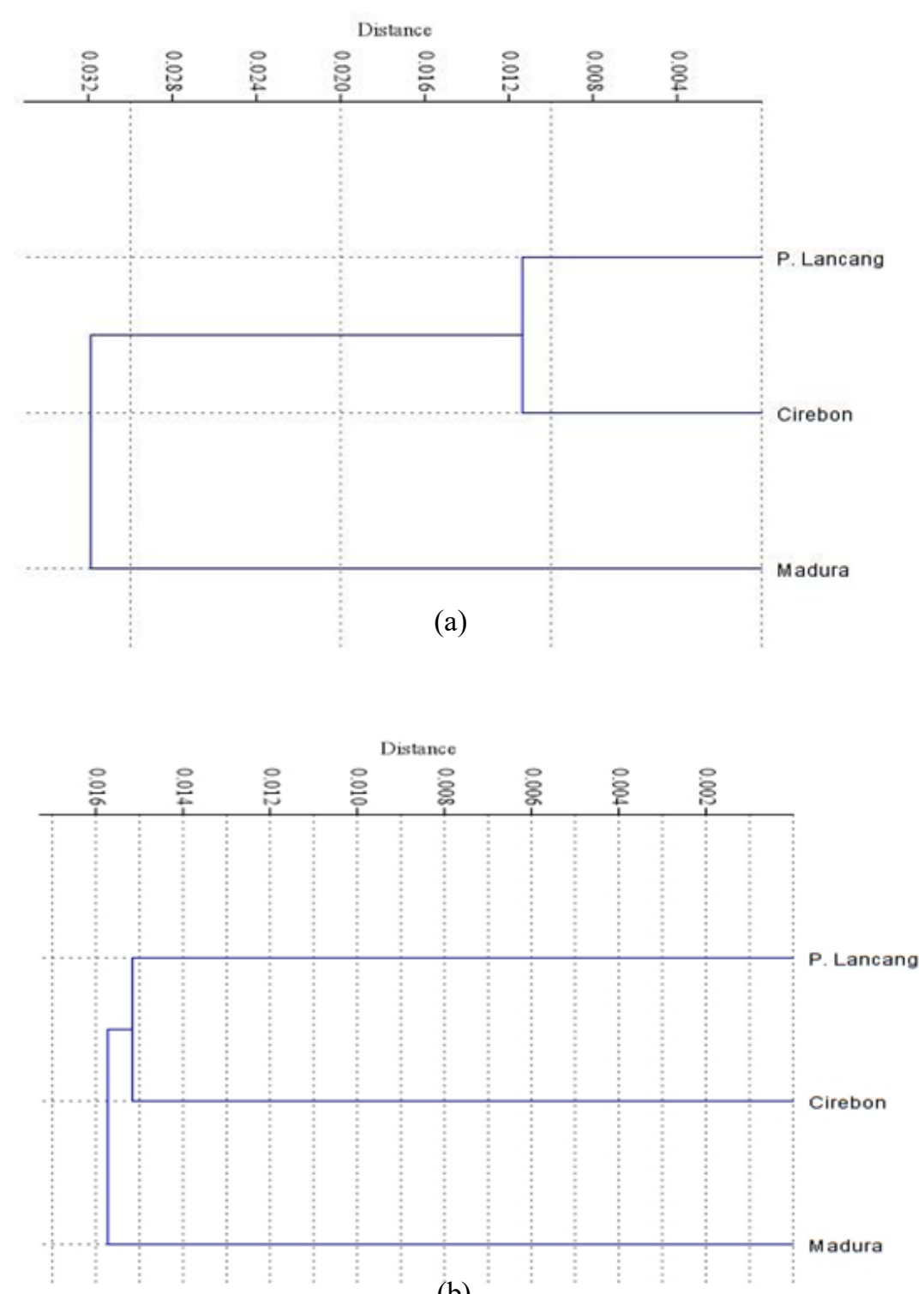

(b)

Gambar 3 Hasil analisis kluster terhadap pengelompokkan rajungan (Portunus pelagicus) (a) jantan dan (b) betina 
Pulau Lancang, Cirebon, dan Selatan Madura saling tumpang tindih. Hal ini menunjukkan adanya kesamaan karakter tertentu pada lokasi. Letak centroid dapat menunjukkan pengelompokkan populasi yang terbentuk secara jelas. Masing-masing populasi rajungan (Portunus pelagicus) jantan yang berasal dari Pulau Lancang, Cirebon, dan Selatan Madura secara tepat sebesar $67,3 \%, 66,7 \%$, dan $76,8 \%$. Adapun untuk rajungan betina yang berasal dari Pulau Lancang, Cirebon, dan Selatan Madura secara tepat sebesar $57,9 \%, 45,1 \%$, dan $60,9 \%$.

\section{Pembahasan}

Analisis mengenai hubungan lebar karapas dan bobot digunakan untuk model penilaian stok. Selain dalam mengestimasi stok suatu populasi, hubungan lebar karapas dan bobot dapat

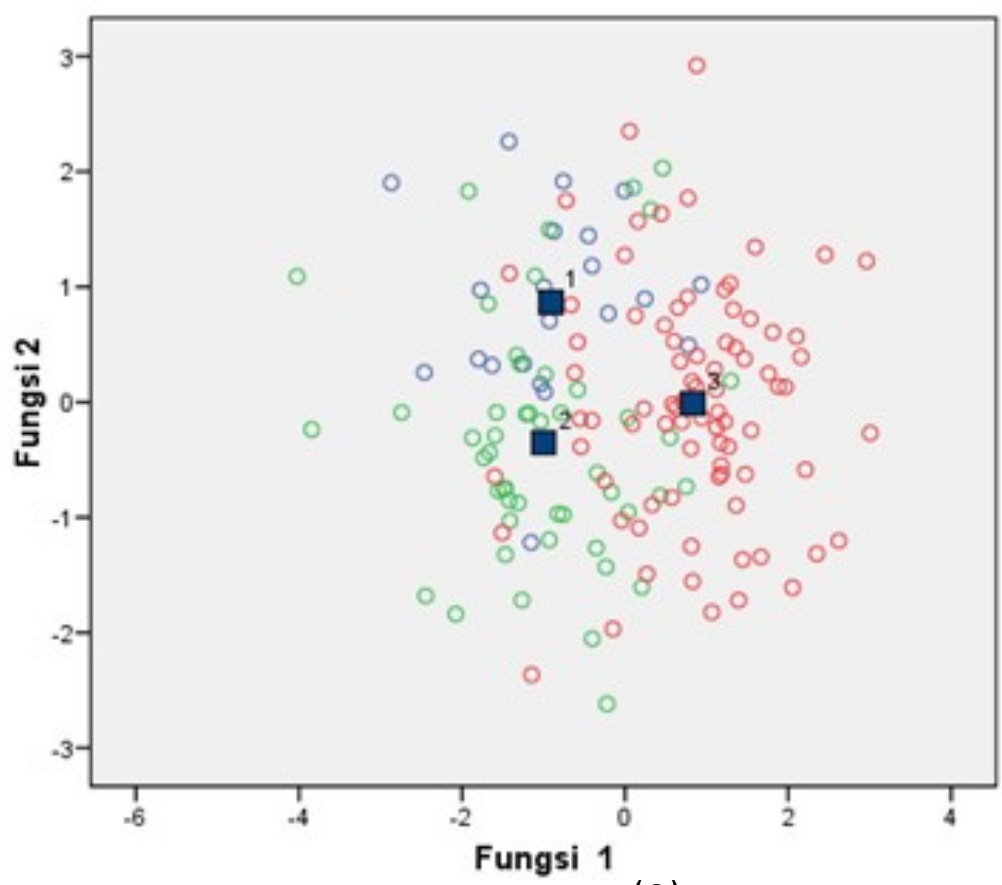

(a)

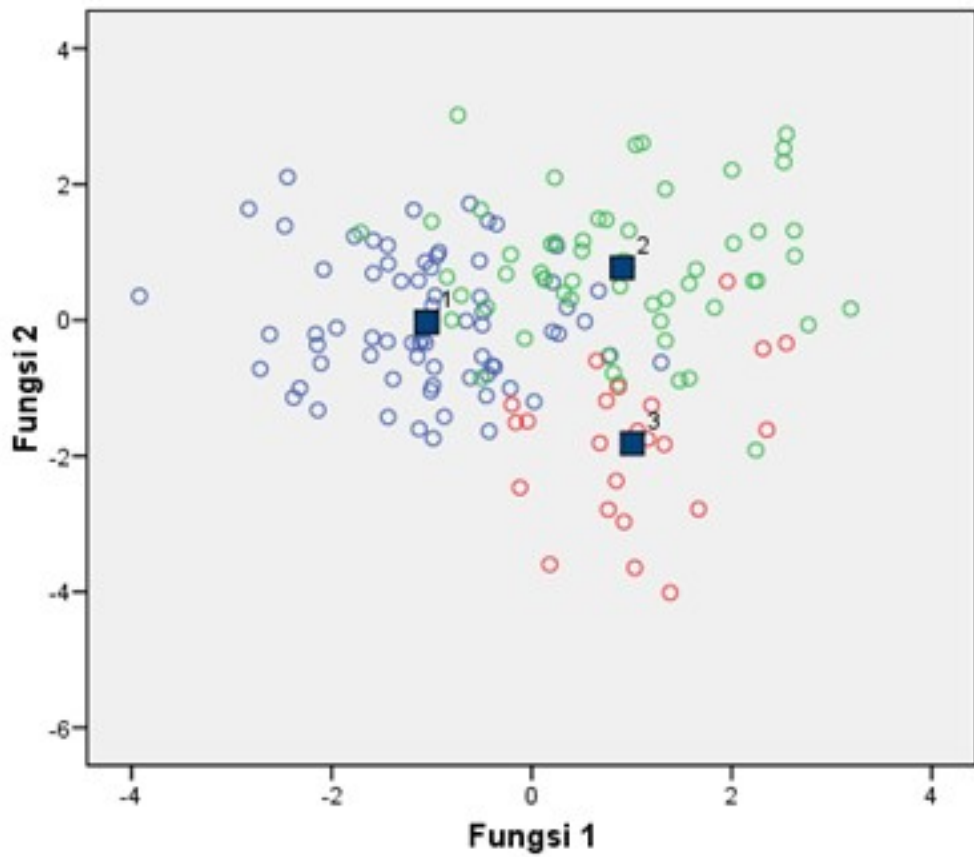

(b)
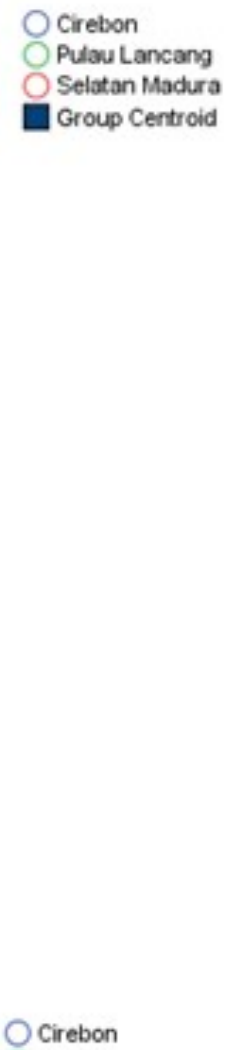

Pulau Lancang

Selatan Madura

Group Centroid

Gambar 4 Hasil analisis diskriminan morfometrik rajungan (Portunus pelagicus) (a) jantan dan (b) betina di Pulau Lancang, Cirebon, dan, Selatan Madura 
memperkirakan eksploitasi serta mengevaluasi populasi krustasea (Josileen 2011). Berdasarkan analisis yang dilakukan pola pertumbuhan yang diperoleh rajungan hampir di setiap lokasi adalah isometrik. Hal ini sesuai dengan hasil yang didapatkan oleh Aini (2017) di Rembang, Pamekasan, dan Pulau Lancang. Namun terdapat juga pola pertumbuhan rajungan yang bersifat alometrik positif yang diperoleh oleh Ernawati et al. (2014) di Pati, Jawa Tengah serta alometrik negatif dari hasil penelitian Setiyowati (2016) di Jepara.

Pola pertumbuhan yang didapatkan memiliki perbedaan di beberapa lokasi serta jenis kelamin. Perbedaan pada pola pertumbuhan terjadi karena adanya perbedaan pada faktor lingkungan, jenis kelamin, umur, serta penyakit (Sumpton et al. 1994). Selain itu, perbedaan juga dapat disebabkan oleh ukuran, kebiasaan makan serta tingkat metabolisme pada hewan (Sukumaran \& Neelakantan 1997). Perbedaan pola pertumbuhan dipengaruhi oleh nilai $b$ yang bervariasi. Nilai $b$ yang bervariasi diakibatkan oleh bentuk dan kegemukan spesies secara musiman serta antarhabitat atau lokasi (Olusoji et al. 2009 in Hamid 2019).

Perbedaan pertumbuhan pada rajungan disebabkan oleh beberapa faktor seperti jenis kelamin, kondisi lingkungan, makanan, dan proses reproduksi (Ernawati et al. 2014). Selain itu, menurut Hartnoll (1982) in Sunarto (2012) perbedaan pertumbuhan rajungan juga disebabkan oleh faktor luar tubuh seperti perbedaan iklim yang diikuti oleh perubahan musim serta faktor dalam seperti tingkat kedewasaan dan kelengkapan anggota tubuh.

Karakter morfometrik digunakan untuk melihat hubungan antarspesies, termasuk pada krustasea (Hidayani et al. 2015). Perbedaan karakter morfometrik diduga terjadi akibat perbedaan kondisi lingkungan yang menyebabkan bentuk adaptasi pada rajungan berbeda. Menurut Lai et al. (2010) karakter morfometrik yang berbeda disebabkan oleh adaptasi yang dilakukan oleh rajungan akibat perubahan kondisi lingkungan baik habitat maupun makanan. Habitat rajungan jantan dan betina berbeda ketika rajungan akan memijah. Rajungan betina akan bermigrasi ke perairan yang lebih dalam dan memiliki salinitas yang lebih tinggi serta substrat berpasir untuk proses penetasan telur (Zarion et al. 2014). Rajungan jantan dominan tertangkap di perairan pantai dibandingkan rajungan betina (Adam et al. 2016). Rajungan jantan lebih senang berada pada perairan yang memiliki salinitas yang rendah, sehingga persebarannya lebih dominan di perairan dangkal. Adapun persebaran rajungan betina lebih dominan di perairan dalam karena memiliki salinitas yang lebih tinggi untuk melakukan pemijahan (Saedi 1997 in Adam et al.
2016).

Populasi rajungan jantan dan betina yang berada di Pulau Lancang dan Cirebon memiliki kekerabatan yang lebih dekat dibandingkan populasi rajungan yang berada di Selatan Madura. Rajungan yang berada di Selatan Madura membentuk kelompok yang terpisah. Kedekatan kekerabatan ini menunjukkan kondisi lingkungan di Pulau Lancang dan Cirebon hampir sama. Menurut Pramithasari (2016), perbedaan kelompok diduga terjadi akibat perbedaan kondisi lingkungan, sehingga menyebabkan kemampuan adapatasi rajungan di Selatan Madura terhadap lingkungannya berbeda dengan kemampuan adapatasi rajungan di Pulau Lancang dan Cirebon. Perairan Madura memiliki kecepatan angin yang relatif kecil, sehingga membentuk gelombang yang tidak signifikan dan cenderung semakin besar tiap minggunya (Siswanto \& Nugraha 2014).

Perubahan lingkungan merupakan pembatas utama karakter morfologi pada tingkat intraspesies (Turan 1999). Kondisi lingkungan yang penting bagi rajungan adalah suhu dan salinitas. Suhu dan salinitas merupakan faktor yang mempengaruhi distribusi, pergerakan, dan aktivitas rajungan (Santoso et al. 2016). Menurut Agus et al. (2016) suhu dan salinitas di Pulau Lancang secara berurutan sebesar $27,9-29,4^{\circ} \mathrm{C}$ dan 29,8-31,7 psu. Adapun besaran suhu dan salinitas di Cirebon menurut Sudirman dan Husrin (2014) sebesar $29,5-30,2^{\circ} \mathrm{C}$ dan $25,2-29,0$ ppm. Sebaran salinitas di perairan Madura memiliki kisaran antara 26-30 ppm dengan ratarata 27,8 ppm, sedangkan suhu di Madura berkisar antara $27-32^{\circ} \mathrm{C}$ (Guntur et al. 2017). Beragamnya karakteristik lingkungan menyebabkan rajungan memiliki kemampuan untuk cepat beradaptasi. Menurut Asphama et al. (2015) rajungan merupakan biota yang memiliki kemampuan adaptasi yang cepat.

Rajungan yang berasal dari Pulau Lancang, Cirebon, dan Selatan Madura memiliki perbedaan karakter morfometrik berdasarkan analisis yang telah dilakukan. Hal tersebut menunjukkan bahwa terdapat potensi lebih dari satu unit stok pada rajungan di ketiga lokasi, sehingga perlu dilakukan evaluasi pengelolaan pada rajungan yang berada di ketiga lokasi tersebut. Perlu adanya pengelolaan rajungan yang berbeda di setiap lokasi. Pengelolaan yang diterapkan perlu dilengkapi dengan beberapa kajian lanjutan mengenai parameter yang mempengaruhi perbedaan karakter morfometrik. Hasil yang telah dikaji dapat dijadikan sebagai bahan pertimbangan untuk pengelolaan rajungan kedepannya. Kajian lanjutan yang telah diperoleh dapat dilengkapi dengan data komponen mengenai karakteristik lingkungan serta analisis genetik terhadap rajungan di ketiga lokasi. 


\section{KESIMPULAN}

Berdasarkan hasil analisis yang telah dilakukan terdapat karakter morfometrik yang berbeda di setiap lokasi. Hal ini dapat disimpulkan bahwa terdapat perbedaan kelompok rajungan di Pulau Lancang, Cirebon, dan Selatan Madura. Perbedaan kelompok ini menggambarkan bahwa rajungan di ketiga lokasi tersebut memiliki potensi lebih dari satu unit stok.

\section{DAFTAR PUSTAKA}

Adam, Jaya I, Sondita MF. 2016. Model numerik difusi populasi rajungan di Perairan Selat Makassar. Jural Ilmu-Ilmu Perairan dan Perikanan Indonesia. 13(2):83-88.

Afifah N. 2017. Morfometri dan sebaran ukuran rajungan (Portunus pelagicus, Linnaeus 1758) di Perairan Pulau Pulau Lancang Kepulauan Seribu [skripsi]. Bogor (ID): Institut Pertanian Bogor.

Agus SB, Zulbainarni NM, Sunuddin A, Subarno T, Nugraha AH, Rahimah I, Alamsyah A, Rachmi R, Jihad. 2016. Distribusi spasial rajungan (Portunus pelagicus) pada musim timur di Perairan Pulau Lancang, Kepulauan Seribu. Jurnal Ilmu Pertanian Indonesia. 21 (3):209-218.

Aini NK. 2017. Analisis morfometrik rajungan (Portunus pelagicus Linnaeus, 1758) di Perairan Utara Jawa dan Selatan Madura [skripsi]. Bogor (ID): Institut Pertanian Bogor.

Asphama AI, Amir F, Malina AC, Fujaya Y. 201. Habitat preferences of blue swimming crab (Portunus pelagicus). Aquaculture Indonesiana. 16(1):10-15.

Edi HSW, Djunaedi A, Redjeki S. 2018. Beberapa aspek biologi reproduksi rajungan (Portunus pelagicus) di Perairan Betahwalang Demak. Jurnal Kelautan Tropis. 21(1):55-60.

Effendie I. 2002. Biologi Perikanan. Yogyakarta (ID): Yayasan Pustaka Nusatama.

Ernawati T, Boer M, Yonvitner. 2014. Biologi populasi rajungan (Portunus pelagicus) di Perairan sekitar wilayah Pati, Jawa Tengah. BAWAL. 6(1):31-40.

Guntur G, Yanuar AT, Sari SHJ, Kurniawan A. 2017. Analisis kualitas perairan berdasarkan metode indeks pencemaran di Pesisir Timur Kota Surabaya. DEPIK. 6(1):81-89.

Hamid A. 2019. Habitat dan aspek biologi rajungan angin, Podophthalmus vigil (Fabricus 1798) di Teluk Lasongko, Sulawesi Tenggara. JIPI. 24(1):1-11.

Hidayani AA, Fujaya Y, Asphama AI, Trijuno DD, Tenriulo A, Parenrengi A. 2015. The morphometric character and mitochondrial 16S rRNA sequence of Portunus pelagicus. Aquaculture Indonesiana. 16(1):1-9.

Josileen J. 2011. Morphometrics and lengthweight relationship in the blue swimmer crab, Portunus pelagicus (Linnaeus, 1758) (Decapoda, Brachyura) from the Mandapam Coast, India. Crustaceana. 84(14):1665-1681.

[KEPMEN] Keputusan Menteri Kelautan dan Perikanan Republik Indonesia. No 79 Tahun 2016. Rencana Pengelolaan Perikanan Wilayah Pengelolaan Perikanan Republik Indonesia 712. Jakarta (ID): KKP.

King M. 2007. Fisheries Biology, Assessment, and Management $2^{\text {nd }} E d$. Oxford (GB): Fishing News Books/Blackwell Scientific Books.

Lai JCY, Ng PKL, Davie PJF. 2010. A revision of the Portunus pelagicus (Linnaeus, 1758) species complex (crustacea: brachyura: portunidae), with the recognition of four species. The Raffles Bulletin of Zoology. 58 (2):199-237.

Mawaluddin, Halili, Palupi RD. 2016. Komposisi ukuran kepiting rajungan (Portunus pelagicus) berdasarkan fase bulan di Perairan Lakara, Konawe Selatan, Sulawesi Tenggara. Jurnal Manajemen Sumberdaya Perairan. 1(3):299-310.

Mojekwu TO, Anumudu CI. 2015. Advanced techniques for morphometris analysis in fish. Journal of Aquaculture. 6(8):1-6.

Muhotimah, Triyatmo B, Priyono SB, Kuswoyo T. 2013. Analisis morfometrik dan meristik nila (Oreochromis sp.) strain larasati f5 dan tetuanya. Jurnal Perikanan. 15(1):42-53.

Muhsoni FF, Abida IW. 2009. Analisis potensi rajungan (Portunus pelagicus) di Perairan Bangkalan-Madura. EMBRYO. 6(2):140147.

Ostertagová E, Ostertag O, Kovac J. 2014. Methodology and application of the kruskalwallis test. Applied Mechanics and Materials. 611:115-120.

Pramithasari FA. 2016. Analisis variasi morfologi dan genetik undur-undur laut Albune symmysta, Linnaeus 1758 (Crustacea: Hippoidea) di Perairan Sumatera dan Jawa [tesis]. Bogor (ID): Institut Pertanian Bogor.

Turan C. 1999. A ote on the examination of morphometric differentiation among fish populatins: the truss system. Turkish Journal of Zoology. 23:259-263.

Santoso D, Karnan, Japa L, Raksun. 2016. Karakteristik bioekologi rajungan (Portunus pelagicus) di Perairan Dusun Ujung Lombok Timur. Jurnal Biologi Tropis. 16(2):94-105.

Sara L, Muskita WH, Astuti O, Safilu. 2016. The reproductive biology of blue swimming crab Portunus pelagicus in Southeast Sulawesi 
Waters, Indonesia. AACL Bioflux. 9(5):1101 -1112 .

Setiyowati D. 2016. Kajian stok rajungan (Portunus pelagicus) di peraira Laut Jawa Kabupaten Jepara. Jurnal DISPROTEK. 7 (1):84-97.

Siswanto AD, Nugraha WA. 2014. Studi parameter oseanografi di Perairan Selat Madura Kaupaten Bangkalan. Jurnal Kelautan. 7(1):41-45.

Steel RGD, Torrie JH. 1993. Prinsip dan Prosedur Statistika: Suatu Pendekatan Biometrik Edisi Kedua. Jakarta (ID): PT Gramedia Pustaka Tama.

Sudirman N, Husrin S. 2014. Status konvensional mutu air laut untuk kehidupan biota dan indeks pencemaran perairan di pesisir Cirebon pada musim kemarau. Jurnal Ilmiah Perikanan dan Kelautan. 6(2):149154.

Sukumaran KK, Neelakantan B. 1997. Lengthweight relationship in two marine crabs, Portunus (Portunus) sanguinolentus (Herbst) and Portunus (Portunus) pelagicus (Linnaeus) from the Karnakata coast. Indian Journal of Marine Science. 26:39-42.

Sumpton WD, Potter MA, Smith GS. 1994. Reproduction and growth of the commercil sand crab (Portunus pelagicus) in Moreton Bay Queensland. Asian Fish Sci. 7(1994):103 $-133$.

Sunarto. 2012. Karakteristik bioekologi rajungan (Portunus pelagicus) di Perairan Laut Kabupaten Brebes [disertasi]. Bogor (ID): Institut Pertanian Bogor.

Zairion, Wardiatno Y, Fahrudin A, Boer M. 2014. Distribusi spasio-temporal populasi rajungan (Portunus pelagicus) betina mengerami telur di Perairan Pesisir Lampung Timur. BAWAL. 6(2):95-102.

Zairion. 2015. Pengelolaan berkelanjutan perikanan rajungan (Portunus pelagicus) di Lampung Timur [disertasi]. Bogor (ID): Institut Pertanian Bogor. 